\title{
The use of a neuromuscular blocking agent could significantly decrease mortality in moderate-to-severe ARDS patients: is moderate ARDS the best indication for neuromuscular blocking agents
}

\author{
Patrick M. Honore, Aude Mugisha, Luc Kugener, Sebastien Redant, Rachid Attou, Andrea Gallerani and \\ David De Bels
}

We read with interest the recent meta-analysis by Chang et al. who investigated the role of neuromuscular blocking agent (NMBA) use in moderate-to-severe acute respiratory distress syndrome (ARDS) and discuss the potential mechanisms involved in the identified improvements due to the use of NMBA in ARDS [1]. They conclude that the use of NMBAs could significantly decrease mortality in moderate-to-severe ARDS patients and decrease the incidence of barotrauma during mechanical ventilation [1]. We would like to make some comments. Firstly, expert opinion challenges the conclusions of Chang et al., suggesting that NMBA use should be limited to the most hypoxemic patients $(\mathrm{PaO} 2 / \mathrm{FiO} 2 \mathrm{ra}$ tio $<120 \mathrm{mmHg}$, based on the subgroup analysis of the ACURASYS study) and not to moderate ARDS [2, 3]. The same authors also recommend that, at the early phase of mild or moderate ARDS, spontaneous breathing should be preserved [3]. Chang et al. note that NMBAs prevent patient-initiated generation of high volumes and active exhalation, facilitate patient-ventilator synchrony, provide protection from ventilator-induced lung injury (VILI), and ultimately reduce mortality in patients with moderate-to-severe ARDS [1]. The beneficial effects of NMBAs likely include not only abolition of patient-ventilator asynchronies, better lung recruitment, and decrease of VILI, but also less oxygen consumption

\footnotetext{
* Correspondence: Patrick.Honore@CHU-Brugmann.be

ICU Department, Centre Hospitalier Universitaire Brugmann-Brugmann

University Hospital, Place Van Gehuchtenplein, 4, 1020 Brussels, Belgium
}

and possible anti-inflammatory effects [3]. In addition, NMBAs are also reported to directly alleviate pulmonary and systemic inflammatory progression [4]. Other authors demonstrated that cisatracurium infusion in ARDS patients increased the end-expiratory transpulmonary pressure, contributing to the reduction of atelectrauma and expiratory derecruitment $[2,5]$. We see that the conclusions of Chang et al. that the use of NMBAs could significantly decrease mortality in moderate-to-severe ARDS patients and decrease the incidence of barotrauma during mechanical ventilation are not the recommendations of the experts focusing upon the most hypoxemic patients. This message seems crucial to us, considering the numerous side effects of NMBAs.

\section{Abbreviations \\ NMBA: Neuromuscular blocking agent; ARDS: Acute respiratory distress syndrome; VILI: Ventilator-induced lung injury}

\section{Acknowledgements}

None.

\section{Authors' contributions}

$\mathrm{PMH}, \mathrm{SR}$, and DDB designed the paper. All authors participated in drafting and reviewing. The authors read and approved the final version of the manuscript.

\section{Funding}

None.

\section{Availability of data and materials Not applicable.}




\section{Ethics approval and consent to participate}

Not applicable.

\section{Consent for publication}

Not applicable.

\section{Competing interests}

The authors declare to have no competing interests.

Received: 24 April 2020 Accepted: 5 May 2020

Published online: 13 May 2020

\section{References}

1. Chang W, Sun Q, Peng F, Xie J, Qiu H, Yang Y. Validation of neuromuscular blocking agent use in acute respiratory distress syndrome: a meta-analysis of randomised trials. Crit Care. 2020;24:54 https://doi.org/10.1186/s13054020-2765-2.

2. Bourenne J, Hraiech S, Rambaud R, Forel JM, Persico N, Guervilly C, Papazian L. Non-ventilatory therapies for acute respiratory distress syndrome. Minerva Anestesiol. 2018;84(9):1093-101. https://doi.org/10.23736/S0375-9393.18. 12328-5 Epub 2018 May 9. Review.

3. Papazian L, Forel JM, Gacouin A, Penot-Ragon C, Perrin G, Loundou A, et al. ACURASYS study investigators. Neuromuscular blockers in early acute respiratory distress syndrome. N Engl J Med. 2010;363:1107-16.

4. Fanelli V, Morita Y, Cappello P, Ghazarian M, Sugumar B, Delsedime L, et al. Neuromuscular blocking agent cisatracurium attenuates lung injury by inhibition of nicotinic acetylcholine receptor-a1. Anesthesiology. 2016;124: 132-40.

5. Guervilly C, Bisbal M, Forel JM, Mechati M, Lehingue S, Bourenne J, et al. Effects of neuromuscular blockers on transpulmonary pressures in moderate to severe acute respiratory distress syndrome. Intensive Care Med. 2017;43: 408-18.

\section{Publisher's Note}

Springer Nature remains neutral with regard to jurisdictional claims in published maps and institutional affiliations. 